\title{
Evaluation of the durability of hydrophobic treatments on concrete architectural heritage
}

\author{
V. Lucquiaud', L. Courard', O. Gérard', F. Michel', M. Handy², S. Aggoun², A. \\ Cousture $^{2}$
}

${ }^{1}$ University of Liège, ArGEnCo Department, GeMMe Building Materials, Belgium

${ }^{2}$ University of Cergy-Pontoise, Laboratory of Mechanics and Materials of Civil Engineering

\begin{abstract}
The protection of historical concrete structures is a challenge for the coming years. Hydrophobic treatment may reduce the deterioration process while providing protection against water penetration. Existing commercial products -mainly silane or siloxane in either water or solvent based formulations- were submitted to different ageing processes including UV radiation, dry-wet cycles, thermal shocks, freeze-thaw cycles, carbonation and their effectiveness has been evaluated on the basis of contact angle, vapour and chloride permeability and, capillarity water absorption. The results obtained clearly show that hydrophobic treatments display a good behaviour under the main ageing conditions.
\end{abstract}

Keywords: hydrophobic, ageing, contact angle, UV radiation, capillary absorption, vapours permeability

\section{History of concrete}

The oldest remaining fragments of concrete from the Roman age have been dated to around the $3^{\text {rd }}$ century BC. The Romans used a mortar of lime and pozzolana mixed with crushed aggregates called opus caementtitius [1]. However, 95\% of the concretes remaining from this period used a simple lime mortar, which is cured slowly by the action of the precipitation of carbon dioxide. This material was used primarily in the manufacture of foundations and buildings. For their civil engineering structures, they used more sophisticated materials as calcined clay (testa) or calcined volcanic stones (carbunculus). These reactive ingredients should not be confused with the traditional pozzolan whose name comes from the city of Pozzuoli near Napoli (Mt Vesuvio), exclusively used for underwater works [2].

During the Middle Ages, concrete recipes were forgotten in favor of natural stones and lime binder construction. In 1818, Louis Vicat, a French engineer, developed the first artificial cement: he discovered the hydraulic properties of clinker, the main component of cement, and proposed the artificial manufacture of Portland cement from 1840 [4]. In the same period, Aspdin [3] composed a mix of clay and limestone to be burned for manufacturing a powder which, after hydration, is similar to the stone of Portland in the U.K. Vicat was also the first to manufacture hydraulic lime in industrial way. The invention of ferro-cement, the precursor of reinforced concrete is usually attributed to Joseph Louis Lambot, who built water-tanks with a "combination of iron and cement" in order to overcome the lack of strength in tension of concrete in 1848 [5]. 
During the second part of the $19^{\text {th }}$ century, the knowledge of the material has significantly improved leading to the development of calculation and design methods and standards. The first lecture was given in Paris at the Ecole des Ponts et Chaussées in 1897 [1]. But only after the World War II did the demand for concrete increase due to urban and infrastructure development. Architects have largely used concretes because of their mechanical performance, economy in time, manufacturing costs, and readily available at any work site.

\section{Cultural heritage in concrete}

Among building structures, concrete monuments, churches and houses are an important part of our cultural heritage and correspond to a period of architectural history which was promising and enthusiastic for the social development of humanity. In 1889, the first entirely concrete based bridge was erected, the Alvord Lake Bridge by architect Ernest Ransome (Fig.1). He used reinforced concrete to build a $20 \mathrm{~m}$ long single arch and $6 \mathrm{~m}$ height bridge [6]. In 1904, the first concrete based skyscraper was erected in Cincinnati, Ohio, the Ingalls Building (Fig.2). Architects used the Ransome's system of casting steel bars inside concrete slabs allowing them to create a rigid structure [7].

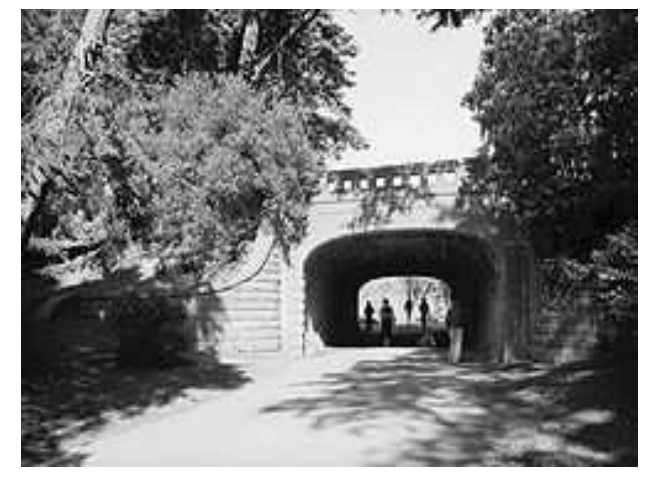

Figure 1. Alvord Lake Bridge by Ernest Ransome, [8]

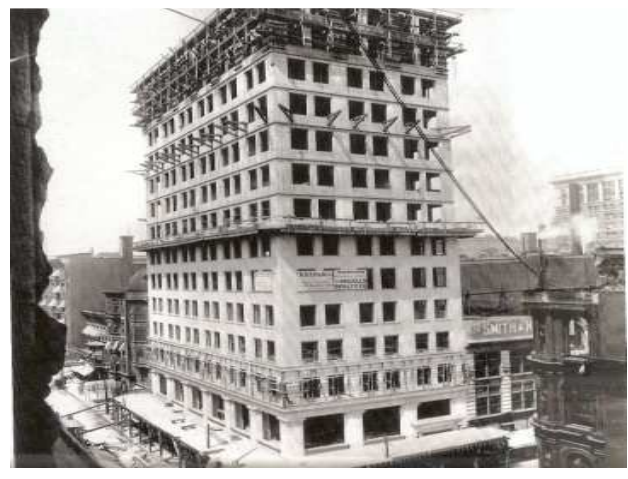

Figure 2. Ingalls Buildings, Cincinnati, Ohio, Elnzer \& Anderson firm [9]

The first religious monument entirely made or cast in concrete is the United Church, a Universalist Unitarian temple, built between 1906 and 1908 by Frank Wright in Oak Park, Illinois (Fig.3). He already played with the texture and the colour of the materials using specific aggregates [10]. This freedom of shapes would have inspired Plečnik, Slovenian architect, to select concrete as the main material for his project in Vienna: the church of the Holy Ghost, erected between 1910 and 1913 [11], is the first church built with this material in Europe (Fig.4). 


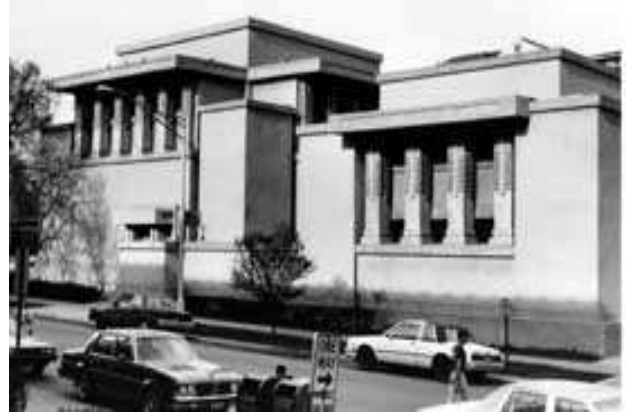

Figure 3. Unity Temple, Frank Wright, Oak Park, Illinois [12]

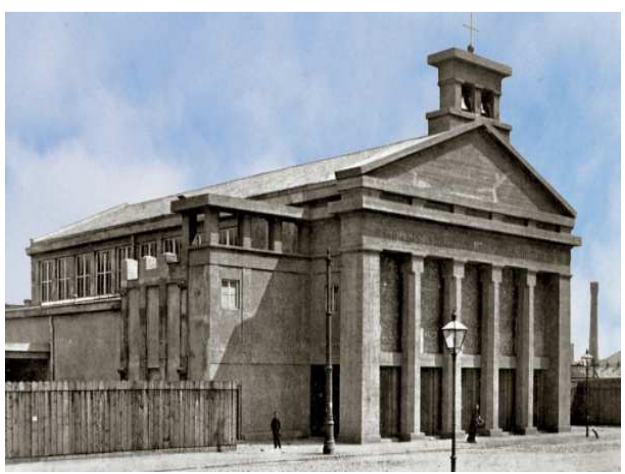

Figure 4. Holy Ghost Church, Vienna, Joze Plecnik [13]

There are many examples of concrete based free shapes in architecture. In the early 50's, Le Corbusier imagines a curved deck bearing on lightly inclined walls for the Chapelle Notre-Dame du Haut de Ronchamp (France) (Fig.5). More recently, emblematic concrete-based religious monument is the Gaudi's Sagrada Familia Church in Barcelona, Spain (Fig.6). This, however, is a counter example of the advantages pointed out by architects: it is still under construction for more than 100 years! Concrete has been definitively a material used not only for developing infrastructure but also for leading architectural and artistic developments [5] designed by architects and urban developers.

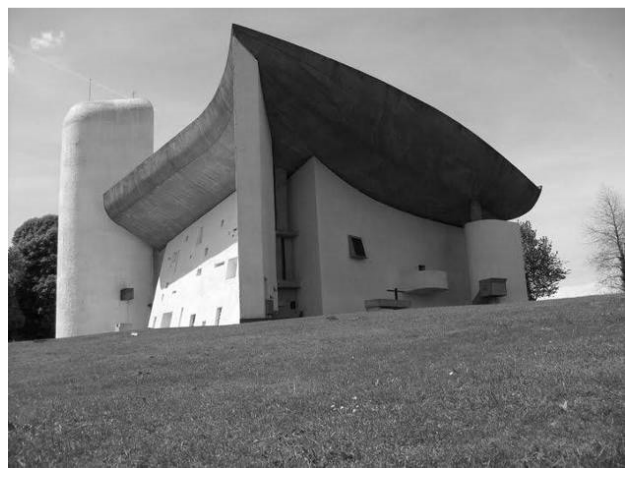

Figure 5. Chapelle Notre-Dame-du-Haut, Ronchamp [14]

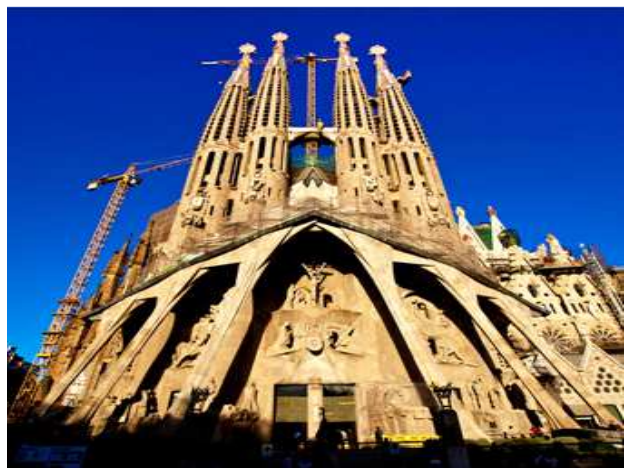

Figure 6. Sangrada Familia Cathedral, Barcelona, Antoni Gaudi [15]

Time always impairs concrete infrastructures. Several damages, such as spallings cracks, disintegration, etc., can appear due to various reasons, such as during carbonation, freeze/thaw cycle or internal chemical reactions [16]. These causes are directly or indirectly related to water presence or infiltrations in concrete. In order to maintain the durability of the structure, reducing water penetration is necessary. Specific needs exist for interventions on historical constructions, such as respect of the original appearance, colour or texture and landscape integration, which include the use of low aggressive surface preparation techniques and selection of high quality aesthetic materials [17]. Hydrophobic treatments are a promising solution and meet all requirements i.e. water repellency and maintaining the original appearance. 


\section{$3 \quad$ Hydrophobic treatments on concrete}

As concrete is a porous material, it is essential to protect it against water penetration: hydrophobic treatments can provide a significant protection system. The EN 1504-2 standard defines hydrophobic impregnation as a concrete treatment for producing a water repellent surface. The inner surface of the pores is coated but the pores are not filled. No film forms on the concrete surface and appearance of the latter is slightly affected or unchanged (Fig. 7). The hydrophobic treatment will reduce the absorption of water, improve chemical resistance, reducing alkali-aggregate reaction and, if applicable, reducing chloride ion penetration.

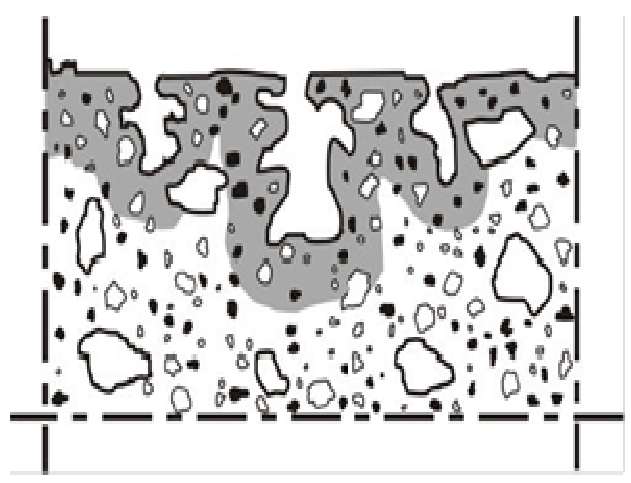

Figure 7. Hydrophobic treatment principle.
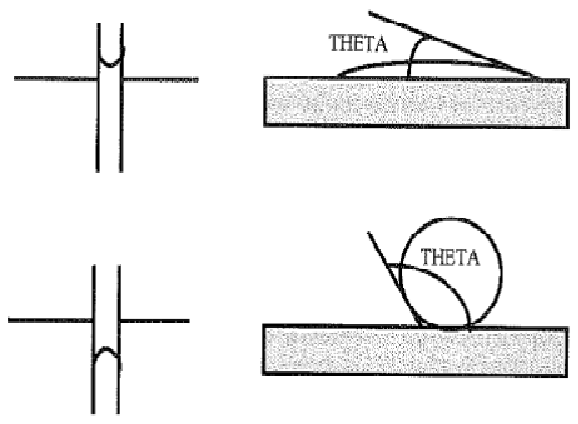

Figure 8. Interaction between water and a hydrophylic (top) or hydrophobic (bottom) concrete surface.

The major objective of a hydrophobic treatment is to increase the contact angle of water (Fig. 8) and reducing surface free energy of concrete or mortar [18]. According to the equation of Young-Dupre (eq. 1),

$$
\left(Y_{S V}-Y_{S L}\right) / Y L V=\cos \theta \quad \text { (equation 1) }
$$

where $Y_{S L}, Y_{L V}$ and $Y_{S v}$ are the solid-liquid interfacial free energy and the surface free energy of liquid and solid into contact with liquid vapour, respectively, and $\theta$ the contact angle (Fig. 4): if $\theta$ is increasing, it means that $\cos \theta$ is decreasing. As YL is constant, it means also that $\gamma_{s}$ is decreasing.

With increasing contact angle, less wetting of the surface will occur. Moreover, it will not penetrate the pore system of concrete if the surface of the pore has been treated: absorption forces become repulsion forces and water is "expulsed" from the surface [19].

Some products induce hydrophobic film formation that badly resists in alkaline media (even if alkalinity was necessary for the initial reaction). But the most common products belong to the silane family. Various kinds of silanes result depending on the different alkoxy or alkyl groups linked to the silicon atom. These products do not act all in the same manner (Fig. 9): in general, the larger the molecule of the alkyl group, the better the water repellency of the silane. The silane molecules are very small (10 to 15 Angstroms) and can penetrate even a very few porous concrete. Penetrations of more than $5 \mathrm{~mm}$ in concrete [20] are observed. 


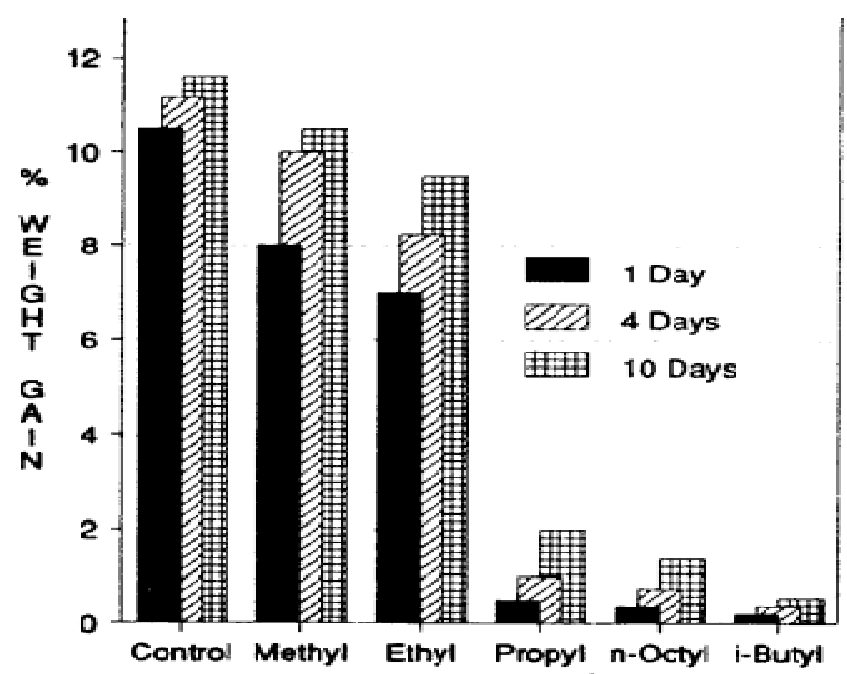

Figure 9. Influence alkyl group type on the hydrophobic efficiency of a silane [21].

Some silanes with alkoxy groups may polymerize if, during the application, they come into contact with water [21]. The water repellency of concrete treated with silanes has been found to be still effective after 35 months exposure to outdoor climate: these products have durable effect on water absorption [20].

A second group of this family is constituted by oligosiloxanes. Siloxanes react with the silica contained in the concrete to form a hydrophobic layer. Siloxane molecules are oligomers and therefore larger than the silane molecules (25 to 75 Angstroms). These products cannot penetrate as deeply into the surface and may not be appropriate for the protection of dense concretes.

In this research project, existing products - mainly based on silanes and siloxanes were subjected to different ageing processes including UV radiation, moistening cycles, thermal shocks, freeze-thaw cycles and carbonation and efficiency has been evaluated on the base of contact angle, capillarity absorption, vapour and chloride permeability.

\section{$4 \quad$ Experimental}

\section{Materials}

The concrete formulation was prepared following standard "NBN EN 1766" using CEM I 52.5 and $\mathrm{W} / \mathrm{C}$ ratio of 0.7 . The design of low quality concrete was intended in order to simulate old concrete coming from cultural heritage. Six batches were prepared with the same mix; each one produced five slabs $(40 \times 40 \times 8 \mathrm{~cm})$. Each slab was cut into four samples of 20x20x8 cm; $8 \mathrm{~cm}$ cylindrical samples were cored into slabs for permeability, capillary absorption and chloride ion diffusion tests. All samples were stored for 28 days in a humid chamber $(90 \% \mathrm{RH})$; and then they were placed in a chamber at $23^{\circ} \mathrm{C}$ and $60 \%$ relative humidity for drying before applying the hydrophobic treatments. Four samples at least are prepared for each combination of test and products.

As the study focuses on the durability of hydrophobic treatments on existing concrete structures, only superficial water-repellents treatments were tested. The products selected correspond to those in used in North Western Europe climate conditions. 
Duplicate sets of samples were treated with either of two products: the first, a waterbased water repellent commercial product. The data sheet defines it as an alkyl alkoxy silane product, henceforth referred to as "water based". The second product was a hydrophobic siloxane mix in an alcoholic solvent, henceforth referred to as "solvent based". The hydrophobic treatments were brushed on to the surface of the samples, following the recommendations of the manufacturer. The studied face is the smooth "mold face". This side is intended to represent the external wall of a building.

\section{Methods}

\section{Permeability to water vapour}

The water-vapour transmission rate was evaluated according to the dish method for free films, following to the ISO 7783 standard [22]. This test uses a difference in relative humidity between the two faces of a sample. The water-vapor permeability rate is determined as a function of the amount of water vapor which passes through the specimen. For this test, cylindrical samples of $8 \mathrm{~cm}$ diameter and $3 \mathrm{~cm}$ thickness were prepared. The lateral faces were waterproofed with epoxy resin. The sample is set on a glass cup and the edges are sealed with wax in order to reduce moisture transfer to only one direction. A saturated solution of potassium nitrate $\mathrm{KNO} 3$ guarantees a relative humidity of $93.2 \%$ in the cup. The device is placed in a conditioning chamber where the relative humidity is $60 \%$ at $20^{\circ} \mathrm{C}$. The thickness of the equivalent air layer is evaluated. The standard proposes also a classification of samples in three classes by water-vapor transmission

Table 1: Classification by water-vapor transmission equivalent layer

\begin{tabular}{|c|c|}
\hline Class & S $_{d}$ (meters) \\
\hline High (I) & $<0,14$ \\
\hline Medium (II) & 0,14 to 1,4 \\
\hline Low (III) & $>1,4$ \\
\hline
\end{tabular}

\section{Liquid water permeability (capillary absorption)}

The measurement of the liquid water transmission coefficient $\mathbf{w}$ was carried out following standard EN 1062-3 [23]. Cylindrical samples with $8 \mathrm{~cm}$ diameter and different of heights were prepared. Only one face is treated with water-repellent, the others are waterproofed with epoxy resin. The treated face is immersed in $5 \mathrm{~mm}$ water and the sample is weighed after $1 \mathrm{~h}, 2 \mathrm{~h}, 3 \mathrm{~h}, 6 \mathrm{~h}$ and $24 \mathrm{~h}$. The coefficient of water-liquid permeability $\mathbf{w}$ is calculated from the slope of the linear part of the curve. 
Table 2: Classification by liquid water permeability

\begin{tabular}{|c|c|}
\hline Class & Liquid water permeability $\mathrm{w}\left(\mathrm{kg} / \mathrm{m}^{2} \mathrm{~h}^{0,5}\right)$ \\
\hline High (I) & $>0,5$ \\
\hline Medium (II) & 0,1 to 0,5 \\
\hline Low (III) & $<0,1$ \\
\hline
\end{tabular}

\section{Chloride ions permeability}

An accelerated chloride permeability test was performed. This test followed standard ASTM C 1202-97 [24]. The test principle is to apply a 60V current passing through the sample. The sample is in contact with both cells through the railings. One cell contains a $0.3 \mathrm{M} \mathrm{NaOH}$ solution and the second a $3 \% \mathrm{w} / \mathrm{v} \mathrm{NaCl}$ solution. The positive terminal of the generator is connected to the $\mathrm{NaOH}$ reservoir and the negative terminal on the $\mathrm{NaCl}$ one (Fig.10). The test consists in measuring the intensity of the current generated by a constant voltage of $60 \mathrm{~V}$ maintained for $6 \mathrm{~h}$. The current induces the $\mathrm{Cl}^{-}$in the sample to move towards the positive terminal; the more chloride ions pass through the sample and the higher the current. The amperage is measured every 30 minutes for 6 hours. Core samples of $8 \mathrm{~cm}$ diameter and $5 \mathrm{~cm}$ thick were used. The lateral faces of the samples were covered with epoxy resin. Before testing, the samples were immersed for one week in a solution of $\mathrm{NaOH}$ for saturation

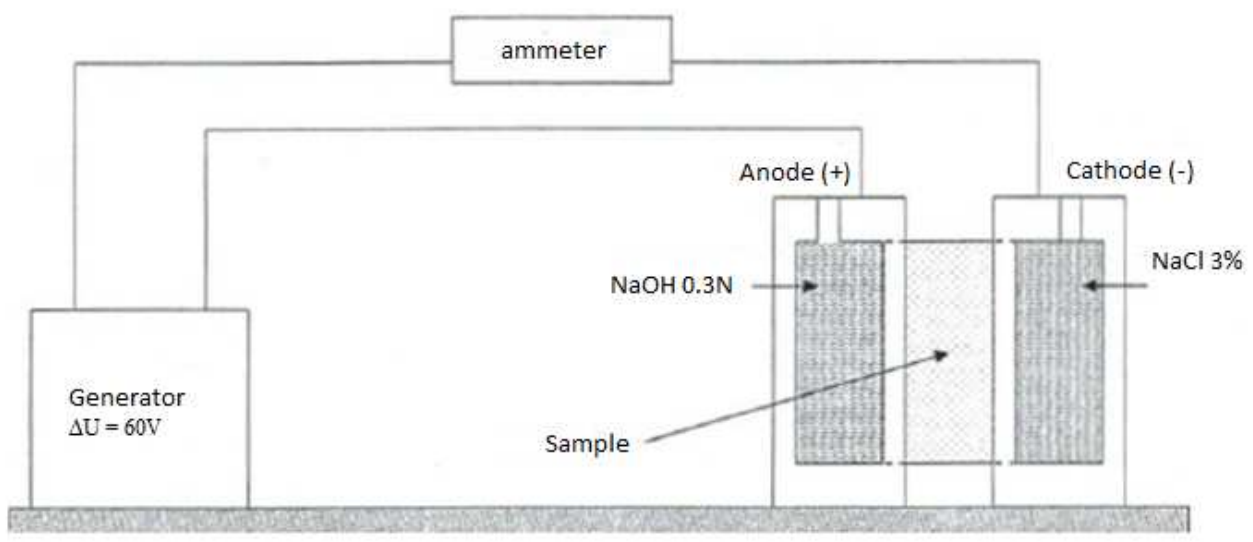

Figure 10. Diagram of the electrical assembly for chloride ion permeability.

Following ASTM C 1202-97 recommendations, the electric charge passing through the sample can be determined as follows:

$$
Q=900\left(I_{0}+I_{30}+I_{60}+\cdots+I_{300}+I_{330}+I_{360}\right)
$$

Where $I_{i}$ is the amperage after i minutes. This equation is valid for sample with a section of $95 \mathrm{~mm}$. A correction is needed:

$$
Q^{*}=Q \times\left(\frac{3.158}{3.75}\right)^{2}
$$


$Q^{*}$ is the electric charge passing through a sample of $50 \mathrm{~mm}(3,158 \mathrm{in})$ of diameter. The standard proposes a classification of samples according to their chloride ions penetrability.

Table 3: Chloride ion penetrability based on charge passed (ASTM 1202-97)

\begin{tabular}{|c|c|}
\hline Charge Passed (Coulombs) & Chloride lons Penetrability \\
\hline$>4000$ & Hoderate (II) \\
\hline $2000-4000$ & Low (III) \\
\hline $1000-2000$ & Very Low (IV) \\
\hline $100-1000$ & Negligible (V) \\
\hline$<100$ & \\
\hline
\end{tabular}

\section{Contact angle measurement}

A water drop is placed with a computer-assisted syringe on to the sample surface. The contact angle between the hydrophobic surface and the droplet of water (Fig.4) is measured by a CDD camera linked to the computer.

\section{Accelerated ageing}

\section{UV light exposition}

To simulate the deterioration process caused by sunlight, the samples were placed in a chamber to expose the treated face with UV-A lamps. The lamps are electrically equivalent to an ordinary 40-watt fluorescent lamp. It provides a simulation of sunlight in the critical short wavelength region from $365 \mathrm{~nm}$ down to the solar cut off of 295 $\mathrm{nm}$. Its peak emission is at $340 \mathrm{~nm}$. This device provides cycles of 4 hours of UV exposition followed by $4 \mathrm{~h}$ of condensation, for a total duration of 700 hours.

\section{Freeze/thaw cycle}

The samples were exposed to 20 freeze/thaw cycles. For each cycle, the samples were immersed for two hours in salted water at $-15^{\circ} \mathrm{C}$ then immersed in water at ambient temperature for two hours. Just one surface is exposed, while the others are sealed with epoxy resin.

\section{Thermal shocks}

Each sample was exposed to infrared lamps $(245 \mathrm{~V}, 250 \mathrm{~W})$ and a water-jet in a storm simulation tank; the face of samples offer slight inclination of about $3^{\circ}$ (relative to the horizontal) to allow water to flow quickly. The surface temperature can reach up to $60^{\circ} \mathrm{C}$. For each cycle, the samples are exposed to infrared lamps for $5 \mathrm{~h} 45 \mathrm{~min}$ and then sprayed with water at $12^{\circ} \mathrm{C}$ for 15 minutes. The samples are exposed to 20 freeze/thaw cycles followed by 10 thermal shocks cycles. Tests were performed on the same samples that underwent freeze/thaw cycles 


\section{RH cycling}

For this test, the six faces of the $20 \times 20 \times 8 \mathrm{~cm}$ samples were treated with one or the other hydrophobic agents and four samples for each agent were tested. The test consists in exposing the samples to four cycles of different relative humidity: each cycle lasts for two weeks: the samples are first stored in an atmosphere of $90 \% \mathrm{RH}$ (for 1 week) and then $50 \% \mathrm{RH}$ (for 1 week).

\section{Carbonation}

The resistance to the carbonation process induced by the applied hydrophobic agent was also assessed. The samples are exposed to carbonation for one month. The conditioning chamber contains a gaseous mix with a $\mathrm{CO}_{2}$ concentration of $50 \%(\mathrm{v} / \mathrm{v})$ and a $60 \% \mathrm{RH}$. The space in the chamber is limited, and small samples $(20 \mathrm{~cm} \times 8 \mathrm{~cm} \times 8 \times \mathrm{cm})$ were used. The hydrophobic agent was applied on the six faces.

\section{$5 \quad$ Results}

The wettability of a surface is directly related to the value of the contact angle between the water droplet and the solid. The contact angle evolution after ageing is given in Figure 11. The contact angle for untreated concrete is below $50^{\circ}$. We note that, before ageing, both products meet already requirements, especially siloxane treated, which leads to high hydrophobic behaviour $\left(145^{\circ}\right)$. The obtained data show that even after subjected to artificial ageing, the products keep their hydrophobic performance. Nevertheless, in two cases, the products lose their performance reaching angles below $90^{\circ}$ : the water based product with UV light exposure and the solvent based with the thermal shocks cycles. The UV light exposition destroys a part the Si-O-Si bonds between the hydrophobic molecules and the substrate, inducing a decrease of the hydrophobic behaviour of the surface. Repeating thermal shocks may cause irreversible structural modifications of the polymer and induce a partial depolymerisation. Moreover, the sudden drop in temperature damaged the quality of the hydrophobic treatment due to differences between the thermal expansion coefficients (concrete/coating). Considering the contact angle standard, the effectiveness of the solvent based product treatment is better than the water based product.

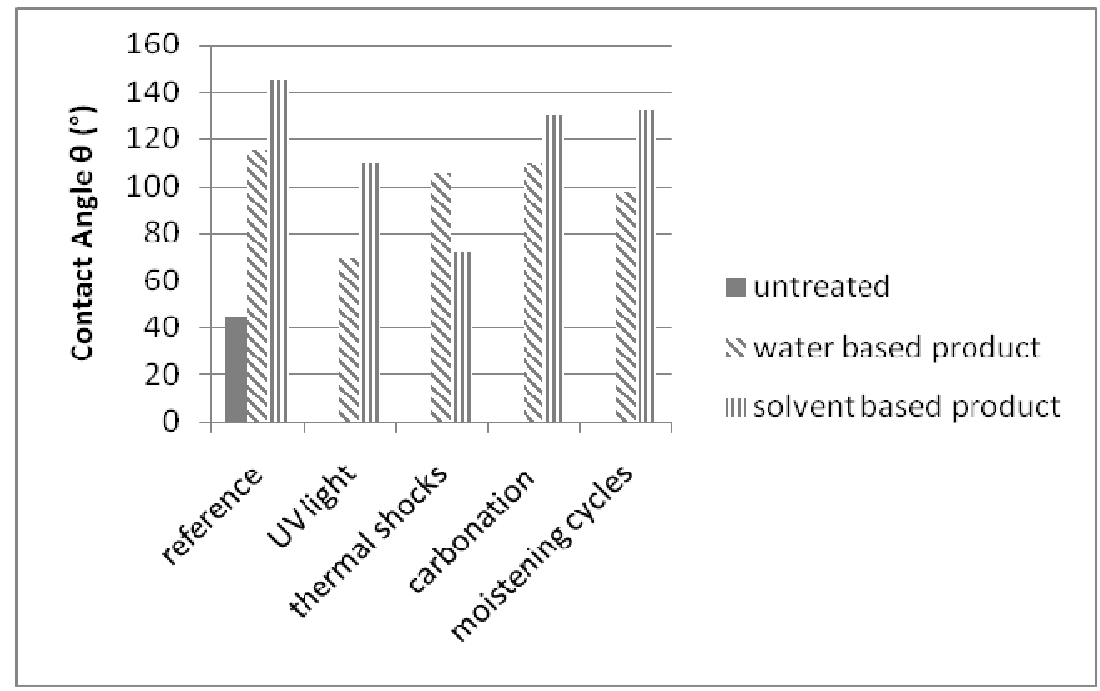

Figure 11. Water contact angles after ageing. 
The efficiency of hydrophobic treatment on water absorption reduction is evident (Fig. 12). The value decreases from $0.112 \mathrm{~kg} / \mathrm{m}^{2} \mathrm{~h}^{0,5}$ for untreated samples to 0.0405 $\mathrm{kg} / \mathrm{m}^{2} \mathrm{~h}^{0,5}$ for solvent based product treated and to $0.0058 \mathrm{~kg} / \mathrm{m}^{2} \mathrm{~h}^{0,5}$ for water based product treated sample. The water based product seems to be more effective as the $\mathrm{w}$ coefficient has a ten-fold decrease compared to sample treated with solvent based product thus significantly reducing water penetration. Most ageing processes slightly degrade the effectiveness of water-repellent with regard to water permeability, but without compromising their performance. In fact, for every ageing process except thermal shocks, the sample remains in the low permeability class $\left(<0.1 \mathrm{~kg} / \mathrm{m}^{2} \mathrm{~h}^{0,5}\right)$.

For the water based product, the coefficient of water-liquid permeability stays at a low value $\left(0.05 \mathrm{~kg} / \mathrm{m}^{2} \mathrm{~h}^{0,5}\right)$ for each ageing process except for thermal shocks. After this ageing, the surface of the water based product treated sample was badly degraded which explains the high coefficient measured after this ageing. On the other hand, the solvent based product treatment offers a good resistance to ageing exposure and stays in the low class permeability. The UV light ageing process is less critical for water absorption performance than for contact angle standard because the Si-O bonds remain intact in the deep on the concrete. The carbonation process tends to reduce the concrete porosity but also the alkalinity that negatively impacts hydrophobic treatments stability.

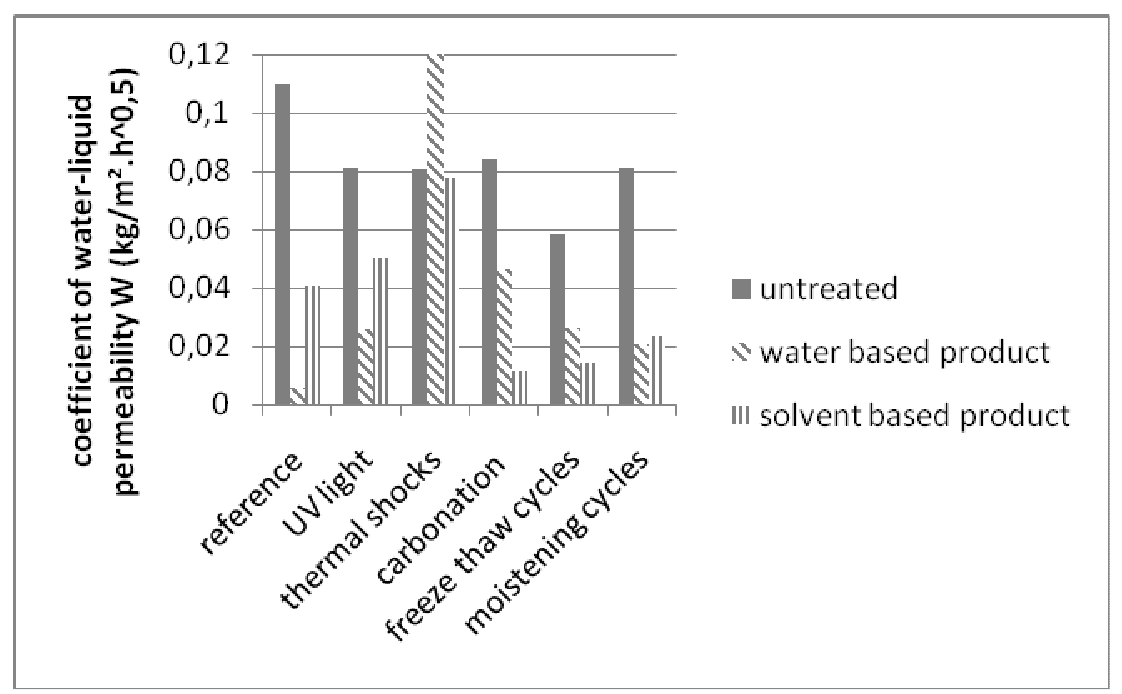

Figure 12. Coefficient of water-liquid permeability w after ageing.

The resistance to chloride ion penetration was performed before after UV light ageing (Fig.13). Before ageing, both untreated and treated samples present moderate chloride ions permeability (II). The values are between $2900 \mathrm{C}$ and $3900 \mathrm{C}$. After UV lights ageing, the chloride penetration resistance is critically diminished by almost twice as much for both water-repellents. For the solvent based product, the corrected charge increases from $2914 \mathrm{C}$ to $4910 \mathrm{C}$, and for the water based product from 3446 $\mathrm{C}$ to $6007 \mathrm{C}$. The treated concretes fall then into another classification group (I) and present a high level of chloride ion penetrability. The solvent based product is more efficient against chlorides penetration than water based product before ageing and after UV treatment. As already mentioned, the UV light partially destroys the Si-O coating/substrate bonds, decreasing the resistance to water-permeability and facilitating the $\mathrm{NaOH}$ solution penetration. 


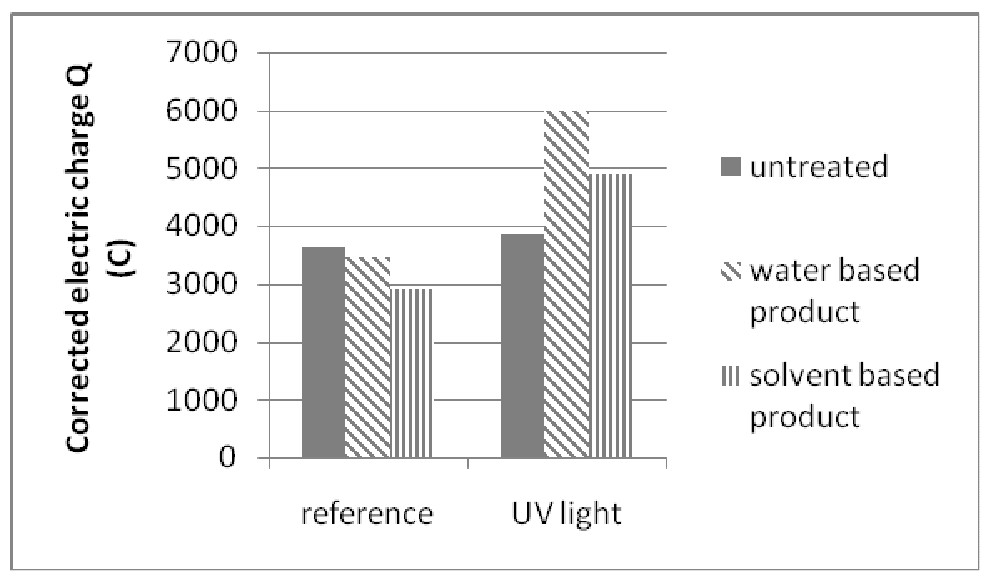

Figure 13. Chloride ion penetration before and after UVA exposure.

As usually requested, the use of hydrophobic agents doesn't significantly modify the water-vapour permeability of concrete. The results show that the concrete has an intrinsic low permeability to water-vapour (Fig.14). Before ageing, the use of the both hydrophobic agents slightly decreases the water-vapour permeability ( $\mathrm{Sd}=3 \mathrm{~m}$ for untreated, $3.6 \mathrm{~m}$ for water based product and $4.3 \mathrm{~m}$ for solvent based product treated, respectively). This significance may be due to $\mathrm{g}$ high silane and siloxane molecular weight (siloxane is bigger than silane) and can reduce the superficial porosity of concrete. After each ageing, the values are close and remain in class III. The differences can be explained by a sampling effect because the intrinsic parameters may have little influence on the results (aggregate placement, variation in porosity, etc.).

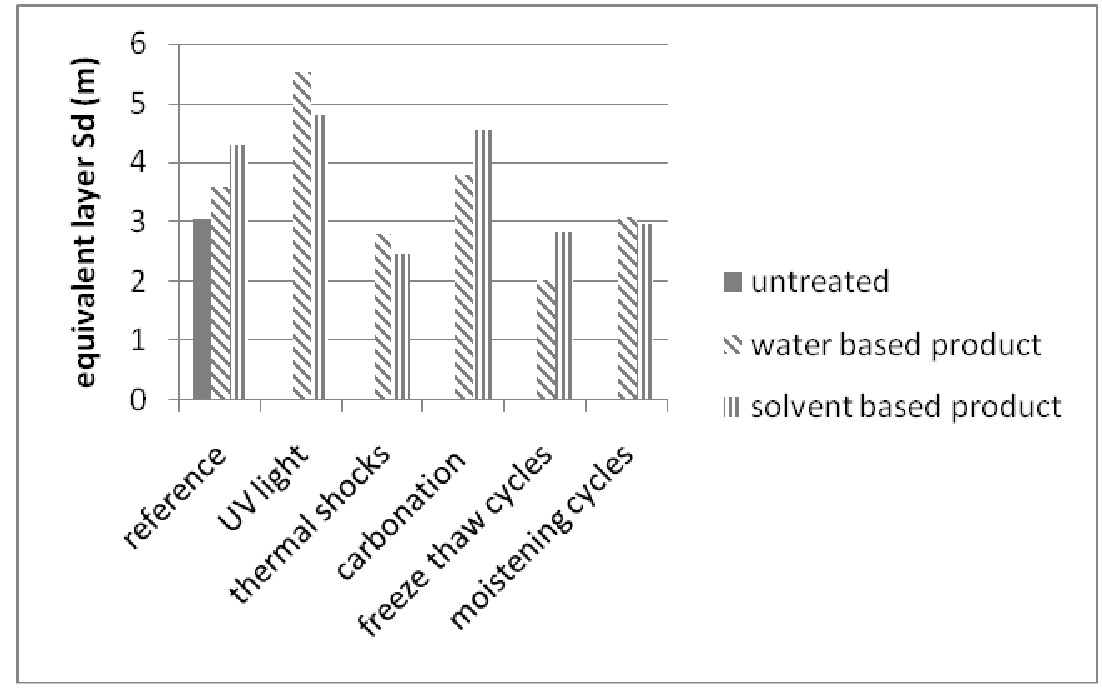

Figure 14. Water-vapour permeability after ageing.

\section{Conclusions}

In order to reduce the natural deterioration of concrete used in cultural heritage buildings, the durability of two water-repellent agents was assessed after various artificial ageing exposures. Five ageing processes were applied on concrete samples treated with the water-repellents and the changes of the measured properties assessed. 
Thermal shocks and UV-A exposure are the most critical ageing process: UV light may break the Si-O-Si bonds of solvent based product molecules at the surface of the concrete; however, molecules that penetrated into it may remain intact. The thermal shocks cause irreversible structural modifications and damage bonds by differential thermal dilatation coefficient.

The hydrophobic treatments tested showed a very low influence on the water-vapour permeability. Such treatments do not prevent the transfer of moisture in and out of the concrete. Regarding the water-liquid permeability and the contact angle, as expected, the products offer a very good behavior and improve the permeability class. In most case, they resist very well to ageing processes and don't lose effectiveness.

The solvent based product tested is more effective than the water based product. It offers better intrinsic properties and proved more durable during laboratory ageing. Moreover, only the solvent based product remains stable and neutral from visual color evaluation after undergoing different ageing procedures. The nature of the solvent can be an explication. The solvent based product uses an alcohol solvent which is more effective than the aqueous solvent, but is more problematic for ecological considerations.

The application of either a solvent- or water-based hydrophobic treatment has an important influence in reducing concrete deterioration and can be a solution for the preservation of cultural heritage that uses this material. It reduces water penetration into concrete and remains effective even after weathering. However, the combination of several ageing factors may affect its durability. This can be remediated by periodical reapplication of these treatments thus avoiding their loss of performance over time

\section{Aknowledgments}

The authors would like to acknowledge the Belgian Science Policy which financially supported the research through BRAIN-be (Belgian Research Action through Interdisciplinary Networks) and REDMONEST-BE2 project.

\section{References}

1. Espion B., Du "ciment" des romains aux débuts du béton armé, Demi-journée d'étude FABI "Connaissez-vous les bétons armés? Des origines à 1914", Ed. Fédération Royale d'Associations Belges d'Ingénieurs Civils, d'Ingénieurs Agronomes et de Bioingénieurs, 26 octobre 2010, Namur (Belgium).

2. Ferguson J. Pantheon of Rome (elevation) A History of Architecture in All Countries 3rd edition. Ed. R. Phené Spiers, F.S.A. London, 1893. Vol. I: 32p.

3. "Joseph Aspdin." Encyclopædia Britannica. Encyclopædia Britannica Online. Encyclopædia Britannica http://www.britannica.com/EBchecked/topic/101833/cement/76637/History-ofcement\#ref609154

4. Picon A., L'art de l'Ingénieur. Constructeur, entrepreneur, inventeur, éditions du Centre Pompidou, Paris, 1997, 598 pp.

5. Simonnet C., Le béton : histoire d'un matériau, Marseille, Ed. Parenthèses, 2005, 219 pp. 
6. Jackson, D. Great American bridges and dams, Ed john Wiley \& Sons, 1988

7. Jones, K., Rolfes, S. "Historic Downtown Cincinnati". Arcadia Publishing, 2011, p. 83.

8. http://www.historicbridges.org/bridges/browser/?bridgebrowser=california/alvord lake/

9. http://openbuildings.com/buildings/ingalls-building-profile-7228

10. Kind-Barkauskas F., Kauhsen B., Polonyi St., Brandt J., Construire en béton. Conception des bâtiments en béton armé, Ed. Presses Polytechniques et Universitaires Romandes, Lausanne (2006) pp. 9-44.

11. Krečic P., Plečnik. Une lecture des formes, Mardaga, Liège (1992).

12. http://en.wikipedia.org/wiki/Unity_Temple

13. http://apointindesign.com/2012/04/04/architect-profiles-joze-plecnik/

14. http://www.archigraphie.eu/?p=331

15. http://www.pilgrimages.com/frcappuccino/

16. Concrete removal techniques: influence on residual cracking and bond strength. B. Bissonnette, L. Courard, A. Vaysburd and N. Bélair. Concrete International, 28[12] (2006) 49-55.

17. Gillard, A., L. Courard, P. Paquet. Churches and concrete in Liège district: history, architecture and pathologies. Restoration of Buildings and Monuments 17[1] (2011) 13-14.

18. Courard, L. How to analyse thermodynamic properties of solids and liquids in relation with adhesion? In: Proc. ISAP '99, 2nd International Symposium on Adhesion between Polymers and Concrete, ed. Y. Ohama, M. Puterman, Rilem Publications, Cachan Cedex (1999) pp.9-20.

19. Courard, L., F. Michel, M. Martin. The evaluation of the surface free energy of liquids and solids in concrete technology. Construction Building Materials 25 (2011) pp.260-266.

20. De Vries, J., R. B. Polder, H. Borsje. 1998. Durability of hydrophobic treatment of concrete. In Proc. CONSEC '98, 2nd International Conference on Concrete under Severe Conditions, ed. O.E. Gjorv, K. Sakai, N. Banthia, E \& FN Spon, London (1998) pp.1341-1350.

21. Courard, L., A. Darimont, R. Degeimbre, J. Wiertz. 2003. Effects of environment on Repair Materials: Results of a Five-Year Research Project. In Proc. Sixth Canmet/ACl International Conference on Durability of Concrete, ed. V. M. Malhotra, American Concrete Institute, SP212-57, (2003) pp.921-940.

22. EN ISO 7783-2:1999. Paints and varnishes. Coating materials and coating systems for exterior masonry and concrete Determination and classification of water-vapour transmission rate (permeability).

23. EN 1062-3:2008. Paints and varnishes. Coating materials and coating systems for exterior masonry and concrete Determination of liquid water permeability.

24. ASTM C 1202-97. Standard Test Method for Electrical Indication of Concrete's Ability to Resist Chloride Ion Penetration. 